Hydrol. Earth Syst. Sci. Discuss., 8, 1507-1540, 2011 www.hydrol-earth-syst-sci-discuss.net/8/1507/2011/ doi:10.5194/hessd-8-1507-2011

(c) Author(s) 2011. CC Attribution 3.0 License.
Hydrology and Earth System Sciences Discussions

\title{
Estimation of future glaciation and runoff in the Tanimas basin, Eastern Pamirs
}

\author{
W. Hagg ${ }^{1}$, M. Hoelzle ${ }^{2}$, S. Wagner ${ }^{3}$, and Z. Klose ${ }^{4}$
}

${ }^{1}$ Department of Geography, Ludwig-Maximilians-University, Munich, Germany

${ }^{2}$ Department of Geosciences, University of Fribourg, Fribourg, Switzerland

${ }^{3}$ Itos-GmbH, Ebnat-Kappel, Switzerland

${ }^{4}$ Department of Water Resources and Environmental Modeling,

Czech University of Life Science, Prague, Czech Republic

Received: 29 December 2010 - Accepted: 25 January 2011 - Published: 28 January 2011

Correspondence to: W. Hagg (hagg@Imu.de)

Published by Copernicus Publications on behalf of the European Geosciences Union. 


\section{Abstract}

A conceptual hydrological model was set up in the upper Panj catchment, the main tributary of Amu-Darya river. Driven by daily temperature and precipitation, the model reproduced daily hydrographs of Tanimas river at the Rukhk gauging station in a very 5 satisfactory way. Based on two glacier inventories from the mid-20st century (WGI, World Glacier Inventory) and from 2003 (GLIMS, Global Land Ice Measurements from Space), a simple parameterization scheme based on steady state conditions was applied to infer the ice volumes and glacier areas for the two different time periods in the past. Assuming temperature rises of $2.2^{\circ} \mathrm{C}$ and $3.1^{\circ} \mathrm{C}$, which mark the extreme values of regional climate scenarios, the same method was used to extrapolate glaciation to the year 2050. The results show that these temperature rises will reduce the current glacier extent of $431 \mathrm{~km}^{2}$ by $36 \%$ and $45 \%$, respectively.

To assess future changes in water availability, the hydrological model input was modified according to the regional climate scenarios and the resulting glacier changes.

15 The use of an elevation distributed deglaciation pattern is a clear improvement over methods used previously, where the impact on runoff was tested by excluding either the lower half or the total glacier area. The runoff scenarios reveal no changes in annual runoff, because the glacier area decrease is balanced out by enhanced melt rates. However, there is an important seasonal shift of water resources from summer to spring, unfavorably affecting agriculture and irrigation in the lowlands.

\section{Introduction}

In many mountain ranges at mid-latitudes, glaciers represent important water reservoirs on several time scales. They are nourished by solid precipitation and release the water again through melting. In climate zones where accumulation and ablation occur at different times of year, this leads to a seasonal delay of runoff (Jansson et al., 2003). When glacier mass balance is disturbed in one direction over a longer period, the
HESSD

$8,1507-1540,2011$

\section{Estimation of future glaciation and runoff in the Tanimas basin, Eastern Pamirs}

W. Hagg et al.

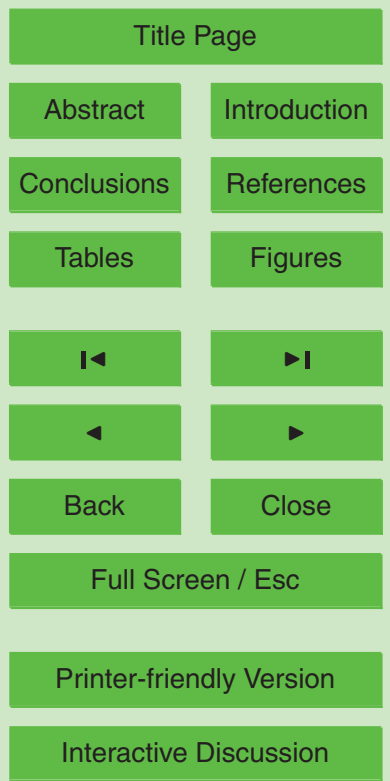


glacier volumes change. In the case of a prolonged phase of mass loss as currently observed on most mountain glaciers, additional water is released and contributes to streamflow. Lambrecht and Mayer (2009) determined the portion of this excess melt in Austrian catchments. From 1969-1998, they found annual values of 1.5-9\% of total 5 discharge, depending on the relative glacier cover. In individual months, this fraction reached $20 \%$, in moderately glaciated basins as well. The mass loss is linked to a decrease in glacier area, which lowers the amount of excess water until the effect of enhanced melt is fully compensated for. A further glacier recession will lead to water shortages (Barnett et al., 2005) and after a complete deglaciation, runoff is controlled by precipitation and snow-melt alone.

A new study by Huss (2011) shows that glaciers contribute substantially to runoff in all major drainage basins in Central Europe. For the last century, a value of $26 \%$ of total runoff was determined for the Rhone catchment (glaciation $0.98 \%$ ), and a value of $7.3 \%$ for the Rhine basin (glaciation: $0.21 \%$ ). Other authors conclude that in climates 15 with relatively high precipitation amounts, the contribution of glaciermelt to total runoff is high only in heavily glacierized sub-basins. Weber et al. (2010) modeled the presentday fraction of icemelt in the upper Danube catchment and determined a value of $35 \%$ for a high-alpine head watershed (Vent, glaciation: 35\%). As the relative glacier cover decreases downstream, the portion of icemelt also drops sharply and reaches $2 \%$ after the confluence of the Inn river with the Danube at Passau (glaciation: $0.5 \%$ ). In summer months the respective values for the two gauges are $50 \%$ and $6-7 \%$ (Weber et al., 2009). The icemelt signal is quickly superimposed by high precipitation sums at the northern margin of the Alps that turn the glacial runoff regime into a nivo-pluvial one.

In reverse, this means that the relative importance of glaciermelt is highest in regions where the ablation season is dry and/or where the mountains are surrounded by arid lowlands. A showcase of such conditions can be found in the basin of the Amu-Darya river, the main tributary to the Aral Sea. In a worldwide comparison of the hydrological significance of mountains, Viviroli and Baumgartner (2004) classified the Amu-Darya
HESSD

8, 1507-1540, 2011

\section{Estimation of future glaciation and runoff in the Tanimas basin, Eastern Pamirs}

W. Hagg et al.

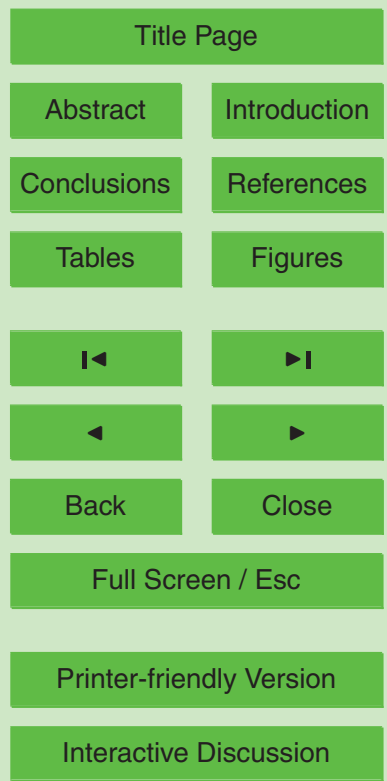


as one of the rivers with the highest share of mountain discharge ( $>90 \%)$, which is defined as the portion of total runoff which is formed in the mountainous part of a catchment. According to Froebrich and Kayumov (2004), about $80 \%$ of the annual runoff of Amu-Darya river is formed by snow- and glaciermelt in the Pamir mountains.

5 Kaser et al. (2010) estimated the contribution potential of seasonally delayed glacier meltwater to total runoff in 18 large river systems on all continents and introduced a population impact index to quantify the potential human dependence on glaciermelt. They found that in the Aral Sea basin, this value is by far the highest of all catchments investigated. Theoretically, a population of more than 10 mill. would suffer from water 10 shortages if the glaciers disappeared. Careless consumption and misuse of water resources make the Aral Sea basin a well-known area of substantial water problems (UNESCO, 2009). The growing demand for water and water use conflicts along the transboundary river increase the need for interdisciplinary approaches to sustainable land and water use in the future (e.g. Martius et al., 2009). This extreme climatological 15 and societal situation makes the region especially interesting for water balance studies. Whereas many authors in the past years worked in lower parts of the Amu-Darya basin where the water is mainly used (e.g. Conrad et al., 2008; Bekchanov et al., 2010), there is a lack of investigations in the runoff-forming zone. This might be due to logistic obstacles to accessing the glacier region of the Pamir, to political instability and to the sparse data coverage, which restricts scientists to very simple methodology.

In remote high-mountain environments, conceptual hydrological models are widely used due to their limited requirement for data. They simulate the hydrological cycle through the use of calibrated and lumped equations on a catchment scale, without describing small-scale physical processes. In spite of parameter intercorrelation and uncertainty, which can be a problem especially outside the calibration period (Uhlenbrook et al., 1999), they are often the only feasible way to reproduce river hydrographs. A variety of conceptual runoff models were used by many different authors in glacierized catchments (e.g. Hock, 2003; Verbunt et al., 2004; Schaefli et al., 2005; Konz et al., 2007; Juen et al., 2007; Koboltschnig et al., 2008), also in combination with glacier
HESSD

$8,1507-1540,2011$

\section{Estimation of future glaciation and runoff in the Tanimas basin, Eastern Pamirs}

W. Hagg et al.

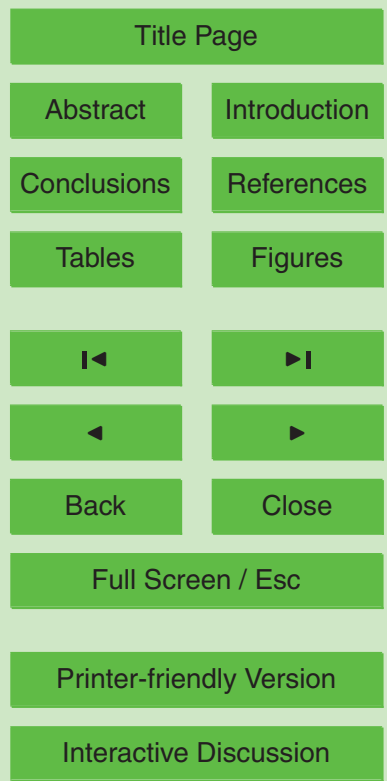


area development based on area-volume scaling (Stahl, 2008) or by parameterizations using ice thickness change patterns (Huss et al., 2008, 2010).

One such conceptual model designed for application in glacierized catchments is the HBV-ETH model. It already proved its robust performance in various studies in the 5 Alps (Braun et al., 2000), the Himalayas (Braun et al., 1993), the Tian Shan (Hagg et al., 2006, 2007) and the Caucasus (Hagg et al., 2010). In heavily glacierized regions, runoff is strongly regulated by glacier melt and a prediction of future discharge requires information about future glacier extent. The absence of such information was a weak point in the HBV-ETH applications mentioned above. By assuming three steps 10 of deglaciation $(100 \%, 50 \%, 0 \%)$ without knowing the timing of their occurrence, the runoff scenarios tended to have the character of a sensitivity study. The $50 \%$ deglaciation scenario was realized by excluding the lower half of the glacier area in the topographic input file, which is a simplification that introduces further uncertainties. Despite these restrictions, this simple methodology was adopted by other authors (e.g. Akhtar 15 et al., 2008), probably due to the difficulties involved in a more realistic prediction of future glacier extent.

Future changes in ice volume and glacier extent can be determined by coupled models for glacier mass balance and ice-flow dynamics (e.g. Jouvet et al., 2009). Since this approach is limited by its substantial field data and computational time requirements, 20 many authors prefer simpler parameterizations for glacier retreat (Schaefli et al., 2007; Huss et al., 2008, 2010).

The overall aim of this contribution is to estimate future hydrological conditions for the middle of this century, a time horizon important for water resources planning. Due to the strong hydrological dependence of arid regions on mountain runoff, the highly glacial runoff regime is conserved far downstream and the results also provide important information about the lower reaches of the basin. On the basis of past and recent glacier inventories, high-resolution digital elevation models and the temperature rise projected by regional climate models, a parameterization scheme based on Haeberli and Hoelzle (1995) is used to predict elevation-distributed glaciation. Implemented in
HESSD

$8,1507-1540,2011$

\section{Estimation of future glaciation and runoff in the Tanimas basin, Eastern Pamirs}

W. Hagg et al.

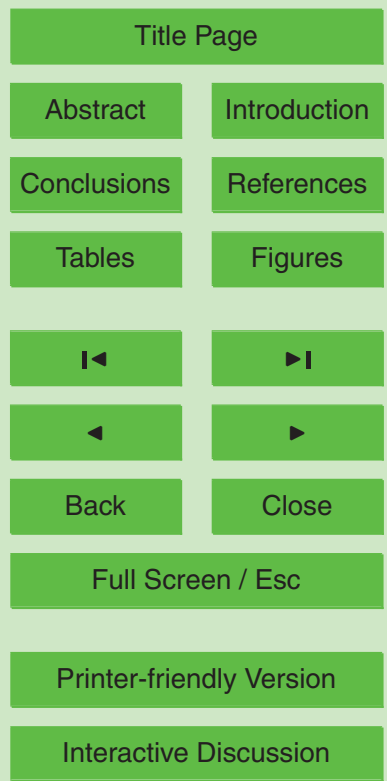


the HBV-ETH precipitation-runoff model, these data enable more realistic runoff scenarios than those from earlier applications to be generated.

\section{Geographical setting}

Amu-Darya is one of the two inflows into the Aral Sea; $68 \%$ of total runoff in the Aral Sea 5 basin is formed in its catchment (UNEP, 2006). While almost $90 \%$ of the total annual discharge of $78 \mathrm{~km}^{3}$ is formed in the mountain areas of Tajikistan and Afghanistan (UNEP, 2006), most of the water consumption takes part in the strongly arid zones of the downstream riparians (Turkmenistan, Uzbekistan).

From Kerki to Nukus, Amu-Darya loses almost all of its water, mainly by artificial use. 10 According to the Interstate Commission for Water Coordination in Central Asia, up to 4 mill. $\mathrm{km}^{2}$ of land in the basin are irrigated (ICWC, 2010), for the most part still using the outdated and inefficient infrastructure from the Soviet period. Another major source of water loss is the Karakum canal which diverts $8-12 \mathrm{~km}^{3}$ from the Aral Sea Basin to Turkmenistan (Glantz, 2005). As a response, Aral Sea has lost $90 \%$ of its volume from 1960 to 2006 (Micklin, 2007).

Amu-Darya is formed at the confluence of the rivers Vakhsh and Panj, the latter contributing $986 \mathrm{~m}^{3} \mathrm{~s}^{-1}$ or $60 \%$ to total runoff. According to the World Glacier Inventory (WGMS, 1989) prepared in the mid 20th century, the Panj catchment has a glacier coverage of $3913 \mathrm{~km}^{2}$, which correspond to a glaciation of $3.4 \%$.

20

Rukhk is a village and hydrological post at the Tanimas river, which becomes the river Bartang at the confluence with the Murghab river (Fig. 1). The catchment $\left(4306 \mathrm{~km}^{2}\right)$ has a glacier cover of $431 \mathrm{~km}^{2}(10 \%)$ and drains the most heavily glacierized part of the Panj basin. Five years of daily discharge data (1985/1986-1989/1990) were compiled at the Rukhk gauge. The hydrographs show a distinct glacial regime with maximum values in July and August. Meteorological data were taken from the Irkht station (3290 m a.s.I) close to Lake Sarez (Fig. 1). This station is located outside the Rukhk catchment, but the close proximity (approx. $23 \mathrm{~km}$ from Rukhk) suggested that

HESSD

$8,1507-1540,2011$

\section{Estimation of future glaciation and runoff in the Tanimas basin, Eastern Pamirs}

W. Hagg et al.

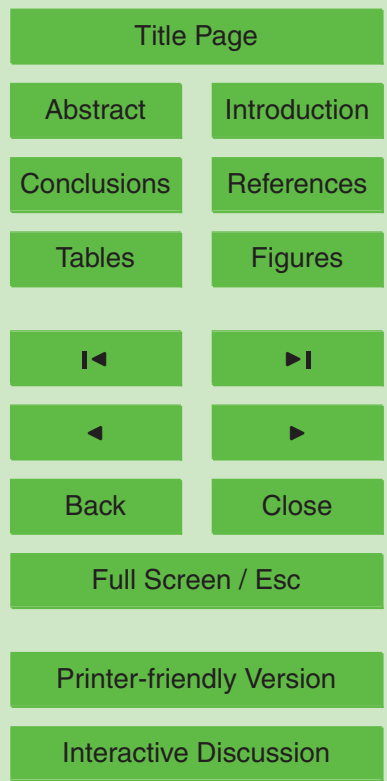


the data are still representative for the meteorology inside the test basin. Irkht offers a valuable long-term series (since 1939) from this strongly continental mountain region. Mean monthly temperatures (1939-1994) range from $-13.6^{\circ} \mathrm{C}$ in January to $14.4^{\circ} \mathrm{C}$ in July, the resulting inter-annual amplitude is $28 \mathrm{~K}$. Mean annual precipitation in the 5 same period is only $139 \mathrm{~mm}, 72 \%$ of which fall from December to May, mostly in solid form. Only $12 \mathrm{~mm}$ or $8.6 \%$ fall in July to August, when $46 \%$ of annual runoff is formed and when the demand for irrigation water is highest. These numbers impressively demonstrate the importance of icemelt in runoff formation and seasonal redistribution.

Agaltseva et al. (2005) conducted regional climate modeling to assess future climate 10 change in the mountainous part of the upper Amu-Darya basin. In order to partly moderate uncertainties of climate models, the averaged results of six Global Circulation Models (HadCM3, ECHAM4, CSIRO-TR, GFDL-TR, CGCM1-TR, CCSR-NIES) were used. The full range of five emission scenarios formed the basis for characterizing climate changes by three time intervals in the future $(2030,2050$ and 2080) with respect tivariate linear regression and is based on observational data from 22 stations in the case of air temperature, and 21 stations in the case of precipitation (Agaltseva et al., 2005). For mid-century, the mean warming in the mountain region ranges from $2.2^{\circ} \mathrm{C}$ (emission scenario A2) to $3.1^{\circ} \mathrm{C}$ (emission scenario A1F1) and is evenly distributed over the year. To cover the full range of possible reactions, we selected these two extreme scenarios to estimate changes in glaciation and runoff. The corresponding precipitation changes for Fedchenko station (4156 m a.s.l), are given in Table 1.

\section{Methods}

\subsection{Glacier model}

25 In order to calculate future discharge, the change in ice volume and glacier extent must be taken into account using parameterizations for glacier retreat (Schaefli et al., 2007; Huss et al., 2008, 2010) or coupled models for glacier mass balance and ice-
HESSD

$8,1507-1540,2011$

\section{Estimation of future glaciation and runoff in the Tanimas basin, Eastern Pamirs}

W. Hagg et al.

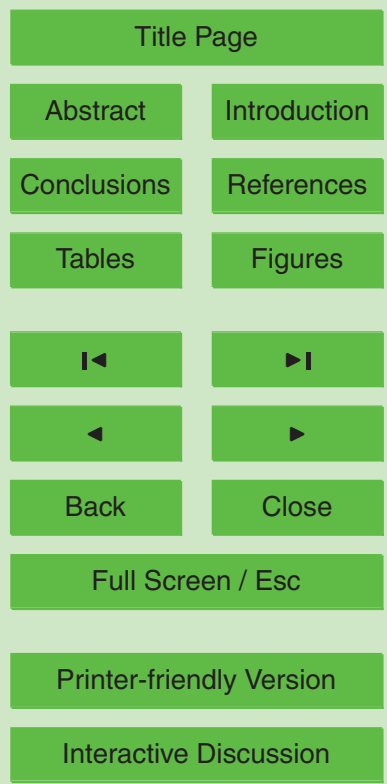


flow dynamics (e.g. Jouvet et al., 2009). However, numerical modelling has some restrictions if it is not applied in a proper way (Le Meur et al., 2004) and the input requirement for fully coupled models increases strongly and processing time is order of magnitudes higher than with the other models. In addition, basal processes have 5 to be parameterized in all model types as well, which is a drawback for the whole modeling process.

The parameterization scheme developed by Haeberli and Hoelzle (1995) provides the possibility to analyze glacier inventory data stored in the databases of WGMS and NSIDC. Detailed information about the complete parameterization scheme can be 10 found in Haeberli and Hoelzle (1995), Hoelzle and Haeberli (1995), Hoelzle et al. (2003, 2007) and Baumann and Winkler (2010). Here, a brief summary of the most important parameterisations is provided. Only five measured input variables from the inventories were used, namely maximum glacier altitude $\left(H_{\text {max }}\right)$, mean altitude $\left(H_{\text {mean }}\right)$, minimum altitude $\left(H_{\min }\right)$, length $\left(L_{0}\right)$ and total surface area $(F)$. All other variables are calculated ing references are cited.

This approach considers the step changes after full dynamic response and new equilibrium of the glacier have been achieved, when mass balance disturbance $\Delta b$ leads to a corresponding glacier length change $\Delta L$ that depends on the original length $L_{0}$ and the average annual mass balance (ablation) at the glacier terminus $b_{\mathrm{t}}$. The term $b_{\mathrm{t}}$ is calculated as $b_{\mathrm{t}}=d b / d h$. $\left(H_{\text {mean }}-H_{\text {min }}\right)$, where $d b / d h$ is the mass balance gradient: $\Delta b=b_{\mathrm{t}} \Delta L / L_{\mathrm{o}}$

Glacier thickness $(h)$ is determined according to Eq. (2) (Paterson, 1994) where $\alpha$ is the slope, $\tau$ the basal shear stress, $\rho$ the density of ice and $g$ the acceleration due to gravity.

$h=\tau / \rho g \sin \alpha$

The dynamic response time $t_{\text {resp }}$ is calculated after Jòhannesson et al. (1989), where $h_{\max }$ is a characteristic ice thickness, usually taken at the equilibrium line where ice
HESSD

$8,1507-1540,2011$

\section{Estimation of future glaciation and runoff in the Tanimas basin, Eastern Pamirs}

W. Hagg et al.

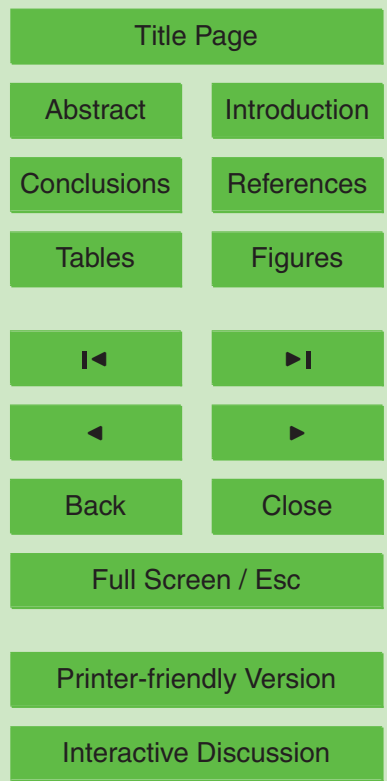

Interactive Discussion 
depths are near maximum. $h_{\max }$ is calculated as $2.5 \mathrm{~h}$, as estimated from known ice thickness measurements on various alpine glaciers worldwide (Bauder et al., 2003; Farinotti et al., 2009, March 2000).

$t_{\text {resp }}=h_{\max } / b_{\mathrm{t}}$

5 Assuming a linear change of the mass balance from $b$ to zero during the dynamic response, the average mass balance $\langle b\rangle$ can be calculated according to Eq. (4). $\langle b\rangle$ values are annual ice thickness change (meters of water equivalent (we) per year) averaged over the entire glacier surface, which can be directly compared with values measured in the field. Although the method is quite simple, the results compare 10 very well with long-term observations (Hoelzle et al., 2003). The factor $n_{\text {resp }}$ denotes the count of possible response times for each glacier within the considered time period.

$<b>=\Delta b / 2 n_{\text {resp }}$

World Glacier Inventory data of the investigation area from two time frames were used. The older data (1940s to 1960s) were derived mainly from aerial photographs, while the second period covers the time between 2000 and 2003 and is based on updated digital outlines (polygons) from the GLIMS database. Nearly all existing glacier polygons had to be corrected for their position and updated using self-digitized polygons. The parameterization scheme was applied to some representative glaciers in both inventories and the results were extrapolated to the whole investigation area to provide an estimation on the total ice volume and the ice volume change for the period 2003 to 2050. Abramov glacier was a reference glacier during the Soviet era and also serves as such in this study. Although it lies $115 \mathrm{~km}$ outside the basin under investigation, it is the nearest glacier that can provide the necessary data. A mass balance gradient of $9.0 \mathrm{~mm} \mathrm{~m}^{-1}$, derived from measured data at Abramov (Pertziger, 1996), was chosen 25 for the entire sample. The parameterization was applied to 82 selected glaciers, where glacier information from both inventories could be compiled. The resulting differences of the modeled volumes were then extrapolated to an overall volume change for the whole test basin.
HESSD

8, 1507-1540, 2011

\section{Estimation of future glaciation and runoff in the Tanimas basin, Eastern Pamirs}

W. Hagg et al.

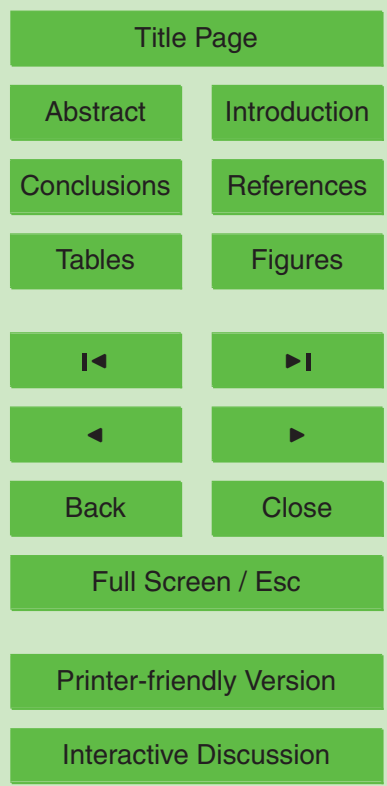

Interactive Discussion 
Mean specific mass balances were estimated using a relation found by Kuhn (1989, 1993), which states that a temperature change of $+1^{\circ} \mathrm{C}$ increases ELA by $170 \mathrm{~m}$ with an accuracy of $\pm 50 \mathrm{~m}$ per degree Celsius. The corresponding change in mass $(\Delta b)$ was calculated using the mass balance gradient $(d b / d h)$ after Eq. (5).

$5 \quad \Delta b=d b / d h d \mathrm{ELA} / d T_{\text {air }} \Delta T_{\text {air }}$

where $d \mathrm{ELA} / d T_{\text {air }}$ describes the vertical shift of ELA per degree Celsius and integrates the change in all climate parameters, i.e. radiation, humidity, accumulation and air temperature, as well as feedback effects for any temperate glaciers (Kuhn, 1993).

The calculation of the $\langle b\rangle$ value was done by taking into account each individual response time and multiples thereof (Eq. 4). According to Eq. (5) an increase in temperature of 2.2 and $3.1^{\circ} \mathrm{C}$ with a corresponding ELA shift of $374 \mathrm{~m}$ and $527 \mathrm{~m}$ would lead to a $\Delta b$ of $3.37 \mathrm{~m}$ and $4.74 \mathrm{~m}$, respectively.

\subsection{Runoff model}

The HBV-ETH model (Braun and Renner, 1992) is a further development of the world- wide used HBV model (Bergström, 1976). At the ETH in Zurich, the main model structure was extended by adding a snow and glacier subroutine to simulate both snow accumulation and the melt of snow and ice. The snow- and glacier-subroutine calculates melt rates of the snow- and ice cover distributed for different elevation belts and aspect classes, while the further steps of the model are performed on a lumped basis for the whole catchment area.

Required input consists of topographical data (distribution of area and exposition classes by altitude, separately for glaciated and total area) and hydrometeorological data (daily values of air temperature and precipitation to drive the model, and runoff for calibration purposes). In the following model description, tuning parameters are in brackets.

A threshold air temperature $(T 0)$ distinguishes snow from rainfall and both aggregational states of precipitation are corrected by factors (SCF, RCF) to account for gauge 1516
HESSD

8, 1507-1540, 2011

\section{Estimation of future glaciation and runoff in the Tanimas basin, Eastern Pamirs}

W. Hagg et al.

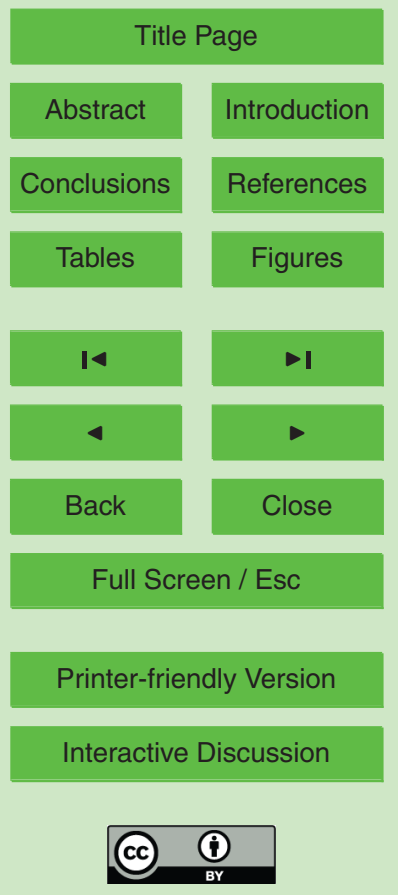


under-catch errors and for the representativeness of the weather station for the catchment. Daily air temperature in every elevation belt is determined using a constant lapse rate (TGRAD). Precipitation is assumed to increase linearly with elevation (PGRAD). Melting of snow and ice is calculated with a temperature index approach using a sea5 sonally variable degree day factor, forming a sinus curve with a maximum (CMAX) and a minimum (CMIN) value at the summer and winter solstice, respectively. Computation of melt rates is corrected for aspect to take into account variations of incoming shortwave radiation. On south-facing slopes melt is multiplied by the factor REXP $(>1)$ while on north-facing slopes it is divided by the same value. The maximum storage 10 of liquid water in the snow pack depends on the snow-water equivalent and is determined by a factor $(\mathrm{CWH})$, while negative melt can be calculated using the coefficient of refreezing (CRFR).

Evapotranspiration is computed as a function of potential evaporation and the fill level of the soil moisture reservoir. Potential evapotranspiration is varies sinusoidally 5 throughout the year with a minimum of zero on 1 February and a maximum (ETMAX) on 1 August. The water flow to the response function is calculated by the field capacity (FC) and a coefficient (BETA). The response function, which has an upper and a lower storage, transforms the water into a flow hydrograph. Three outflows with different response times are calculated by constants $\left(k_{0}, k_{1}, k_{2}\right)$. Quick runoff only appears

20 if the fill level of the upper storage exceeds a certain threshold (LUZ). Percolation from the upper to the lower storage is controlled by the constant CPERC. At the end, the three outflows are summed up to form total runoff.

\subsection{Processing of input data}

Topographic model input consists of a distribution of area by altitude and exposition 25

classes, separately for glaciated and non-glaciated areas. For the Rukhk catchment, this data were calculated from digital elevation models (ASTER-GDEM, $30 \mathrm{~m}$ resolution). The catchment was divided into $300 \mathrm{~m}$ elevation bands and into three exposition classes (South, North and East-West-Horizontal, see Fig. 2). This allows to distinguish

\section{HESSD}

$8,1507-1540,2011$

\section{Estimation of future glaciation and runoff in the Tanimas basin, Eastern Pamirs}

W. Hagg et al.

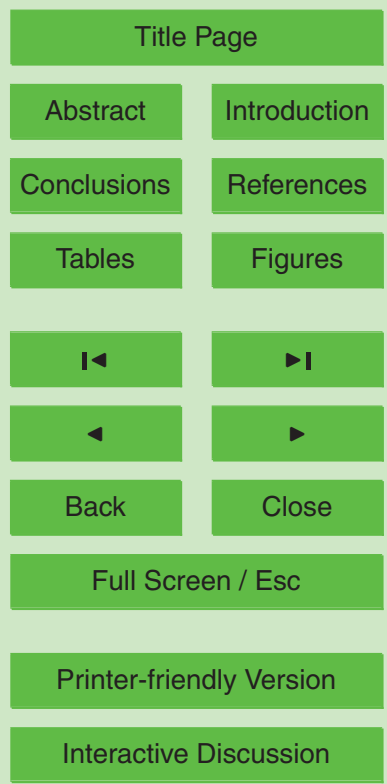


between liquid and solid precipitation in each elevation band and to account for different melt rates on south-and north-exposed slopes. Terrain with slopes smaller than $5^{\circ}$ was classified as horizontal and has the same melt rates as east- and west-exposed slopes. The ASTER images used to generate the elevation models were taken in the period 5 2000-2006. This means a time gap between the topographic and hydrometeorological input of 10-20yr. Since no maps or elevation models from the 1980s are available and due to the lack of better options, this inaccuracy was accepted. A comparison of data from the GLIMS (Global Land Ice Measurements from Space) project with the World Glacier Inventory (WGI) revealed that from the mid 20st century until 2003, glacier area 10 in the whole Panj basin decreased by $8.2 \%$ only (Hoelzle et al., 2010), equaling a mean rate of less than $2 \%$ per decade.

\section{Results and discussion}

\subsection{Deglaciation}

The temperature rises of $2.2^{\circ} \mathrm{C}$ and $3.1^{\circ} \mathrm{C}$ until 2050 reduce the current glacier extent 15 by $36 \%$ and $45 \%$, respectively. The deglaciation in the elevation classes of the HBVETH model is depicted in Fig. 3.

In the two lowest intervals below 4400 ma.s.I, glaciers practically disappear. In the following three intervals up to $5000 \mathrm{~m}$ a.s.l, glacier area is reduced by more than $50 \%$, from $5000-5300$ ma.s.l by $28-36 \%$ and above $5300 \mathrm{~m}$ a.s.l there are only very minor changes. Regarding the current distribution, the largest absolute losses $\left(56-74 \mathrm{~km}^{2}\right)$ will occur between 4700 and 5000 ma.s.l.

The parameterization scheme used to derive future glaciation does not allow to differentiate between the exposition classes used in the hydrological model. It was assumed that relative deglaciation is similar for all expositions.
HESSD

$8,1507-1540,2011$

\section{Estimation of future glaciation and runoff in the Tanimas basin, Eastern Pamirs}

W. Hagg et al.

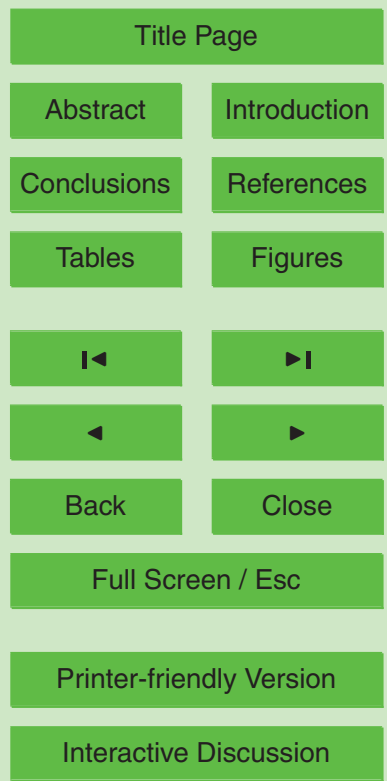




\subsection{Runoff model calibration}

The HBV-ETH model was calibrated manually by tuning the free parameters in a way that minimizes deviations between simulated and measured runoff. The numerical criterion used is the model efficiency after Nash and Sutcliffe (1970), which equals

51.0 when the two curves are identical. Unfortunately, only five years of observations were accessible for this gauge. This allows calibration, but is barely enough to make a separate period for validation, because the characteristics of the individual years can influence calibration if only very few years are used. In any case, it was tested to calibrate the model by the first two years only and to validate it with the following three years. The resulting model efficiencies were $R^{2}=0.88$ and $R^{2}=0.86$ for the calibration and validation period, respectively. When calibrated over the full five years, $R^{2}$ is 0.87 (Fig. 4). The values of all free parameters found by this optimization procedure are listed in Table 1.

The model provides the possibility for an additional quality check by comparing simulated glacier mass balances with field observations (Braun and Aellen, 1990). Since both basin precipitation and glaciermelt are difficult to simulate correctly, a cross-check with measured mass balance data helps to avoid error compensation (Hagg et al., 2004; Schaefli and Huss, 2010; Konz and Seibert, 2010). Unfortunately, no direct observations are available in the investigation area. In any case, moderate mass losses compared to more maritime mountain ranges were also confirmed by repeat photographs in the Tanimas valley (Braun and Hagg, 2009) and by a new GPS survey on Fedchenko glacier in 2009 (Lambrecht et al., 2010). As a consequence, the only frame we had to constrain parameters in terms of icemelt was to avoid strongly negative mass changes, balanced conditions or a gain in glacier mass.

25 Since daily variations in runoff (which are assessed by the Nash-Sutcliffe criterion) are not essential for the evaluation of future water availability, the ability of the model to reproduce monthly runoff was tested (Fig. 5).
HESSD

8, 1507-1540, 2011

\section{Estimation of future glaciation and runoff in the Tanimas basin, Eastern Pamirs}

W. Hagg et al.

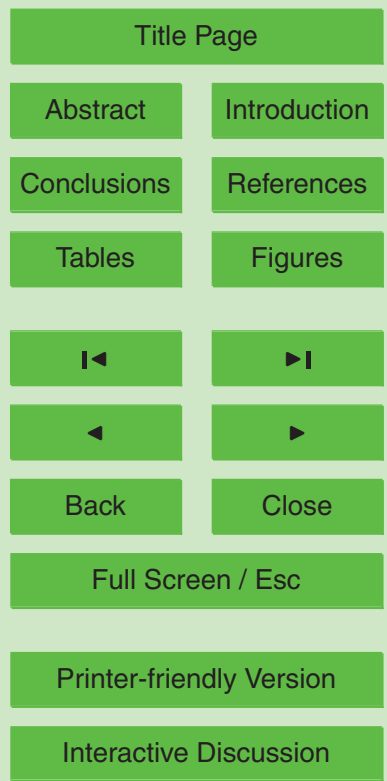


The comparison of modeled and measured monthly runoff shows a high coefficient of determination (0.96) and proves that the model performs well on a monthly time step.

While the use of daily data enables a differentiated evaluation of the model perfor5 mance, the hydrological regime and the temporal distribution of water resources become more clearly visible if monthly means are calculated (Fig. 6). The only month with a minor deviation among the mean values is August, where the model underestimates runoff by $11 \%$ compared to the observational data.

\subsection{Runoff scenarios for 2050}

10 Runoff scenarios were generated by modifying the meteorological model input by a constant temperature shift throughout the year and by seasonal precipitation adjustments according to Table 1.

Glacier changes (Fig. 3) were considered in the area-altitude distribution. The monthly hydrographs of the scenarios are displayed in Fig. 7.

15 Numerical changes are listed in Table 2. For the sake of a better comparability, absolute runoff values have been transformed into relative changes.

It is important to note that annual runoff remains stable, while the seasonal distribution shift towards a water surplus in May-June and a shortage in July-September. The runoff increase in spring and early summer is stronger in the warmer scenario, it can be attributed to an earlier and intensified snowmelt. In July, the glacier area decrease in the two scenarios overcompensates enhanced melt rates due to warming, resulting in lower runoff values when compared with the calibration period. The stronger water shortage occurs in the warmer scenario, indicating that glacier area is the key factor controlling meltwater yield. In August and September, both scenarios show an identical decrease in monthly streamflow compared to the current situation.

The availability of areal changes by altitude is a real improvement over former studies, where deglaciation was simulated by "cutting" the lowest glacier parts. In order
HESSD

8, 1507-1540, 2011

\section{Estimation of future glaciation and runoff in the Tanimas basin, Eastern Pamirs}

W. Hagg et al.

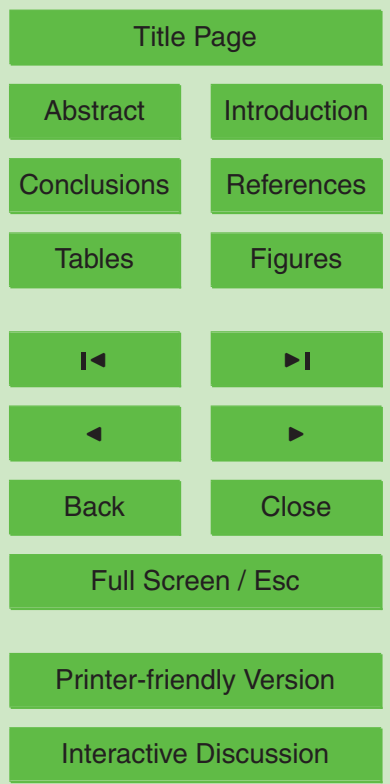


to determine the differences between these two approaches, additional model runs have been performed with the old deglaciation procedure ("cutting lowest"). Results are shown in Table 3.

By cutting the lowest areas, the glaciers lose their most melt-relevant parts. An 5 elevation distributed deglaciation also affects higher reaches and as a consequence preserves glacier areas in lower elevation bands, if the same total area loss is assumed. This leads to an underestimation of runoff for the model runs in the "cutting lowest" mode. Total summer (Jun-Sep) runoff is underestimated by $8.8 \%$ in the moderate scenario (A2) and by $5.6 \%$ in the warmer scenario $(\mathrm{A} 1 \mathrm{~F} 1)$. This error is not 10 large and it diminishes with deglaciation, because the absolute differences between the approaches also decrease with total glacier area. In any case, we believe that the elevation distributed deglaciation approach is a step towards more realistic runoff scenarios.

The HBV-ETH model simulates not only runoff, but also other terms of the water 15 balance. Their average values are listed in Table 4.

According to the presented combination of climate modeling, glacier area parameterization and runoff modeling, neither annual precipitation nor runoff will change significantly until 2050. The areal glacier losses are compensated almost exactly by the enhanced melt rates in the warmer atmosphere.

All values in Table 4 relate to the entire catchment. Therefore, the glacier storage changes have to be regarded as basin values, not as glacier mass balances. Considering the respective glaciation (calibration period: $10 \%$, scenario $\mathrm{A} 2$ : $6.4 \%$, scenario A1F1: $5.5 \%$ ), the specific glacier net balances are $-1100 \mathrm{~mm} \mathrm{a}^{-1}$ for the calibration period, $-1550 \mathrm{~mm} \mathrm{a}^{-1}$ for the A2-scenario and $-2016 \mathrm{~mm} \mathrm{a}^{-1}$ for the A1F1-scenario.

\section{HESSD}

8, 1507-1540, 2011

\section{Estimation of future glaciation and runoff in the Tanimas basin, Eastern Pamirs}

W. Hagg et al.

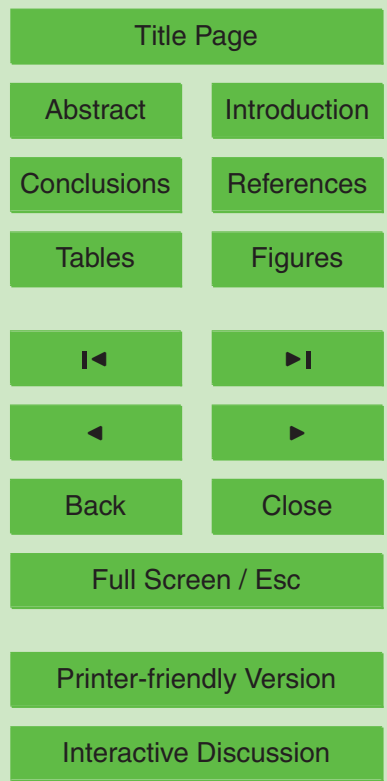




\section{Conclusions}

Including the projected climate and glacier changes, the hydrological model generates an annual runoff which is similar to the calibration period in the 1980s. Changes in precipitation and evapotranspiration are negligible and enhanced glacier melt rates are 5 compensated by a distinct reduction of glacier area. In other words, glacier will melt more strongly but over a smaller area. The seasonal peak runoff is shifted towards May and June. Due to the robust performance of the temperature index approach, these melt-related processes can be predicted with rather good accuracy. We estimate the error in monthly runoff to be less than $20 \%$. The greatest uncertainty is related to future precipitation sums and their seasonality. The GCMs fail in part to model precipitation accurately across varying elevations (Agaltseva et al., 2005). Uncertainties arise at all stages of the modeling process (Meehl et al., 2007), and especially in mountain regions, the confidence in the projected precipitation change remains weak. Differing precipitation sums and intra-annual changes would influence future runoff in two main summer, both affecting the glacier mass balance and consequently the future glacier extent. Liquid precipitation that falls on ice and rock surfaces runs off immediately and in this arid region even small absolute changes would have a large impact on runoff formation. Unless climate models perform better in mountainous terrain this is a source of error which cannot be avoided.

The mean runoff reduction in July and August of approximately $25 \%$ will raise major problems for irrigation and drinking water supply. Irrigation capacities are already limited by summer runoff and a further decrease will intensify the situation in the lowlands. Furthermore, evapotranspiration losses in the downstream regions will be significantly ability in summer. The transnational character of the Amu-Darya requires multilateral planning of adaption strategies and impact mitigation to secure the livelihood of the population.

HESSD

8, 1507-1540, 2011

\section{Estimation of future glaciation and runoff in the Tanimas basin, Eastern Pamirs}

W. Hagg et al.

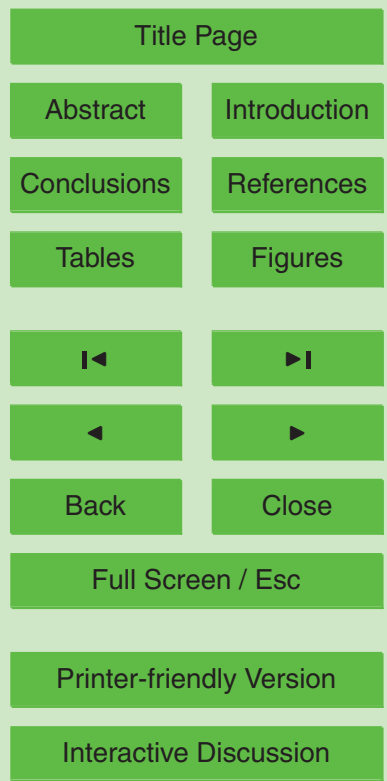


We trust that the applied methodology is a practical but also reliable way to estimate future water availability in regions with little data. The incorporation of real estimates of future glacier areas and the consideration of elevation distributed area changes in particular improved the validity of the results and the power of the approach to deliver 5 predictions.

Acknowledgements. The authors thank Susan Braun-Clarke for editing the English in a very professional way.

\section{References}

Agaltseva, N., Spectorman, T., White, C., and Tanton, T.: Modelling the future climate of the Amu Darya Basin, in: Interstate Water Resource Risk Management: Towards a Sustainable Future for the Aral Basin, edited by: Olsson, O. and Bauer, M., IWA Publishing, London, UK, 2005.

Akhtar, A., Ahmad, N., and Booij, M. J.: The impact of climate change on the water resources of Hindukush - Karakorum - Himalaya region under different glacier coverage scenarios, J. Hydrol., 355, 148-163, 2008.

Barnett, T., Adam, J., and Lettenmaier, D.: Potential impacts of a warming climate on water availability in snow dominated regions, Nature, 438, 303-309, 2005.

Bauder, A., Funk, M., and Gudmundsson, G. H.: The ice-thickness distribution of Unteraargletscher, Switzerland, Ann. Glaciol., 37, 331-336, 2003.

20 Baumann, S. and Winkler, S.: Parametrization of glacier inventory data from Jotunheimen/Norway in comparison to the European Alps and the Southern Alps of New Zealand, Erdkunde, 64, 155-177, 2010.

Bekchanov, M., Lamers, J. P., and Martius, C.: Pros and Cons of Adopting Water-Wise Approaches in the Lower Reaches of the Amu Darya: A Socio-Economic View, Water, 2, 200$25216,2010$.

Bergström, S.: Development and Application of a Conceptual Runoff Model for Scandinavian Catchments, Department of Water Resources Engineering, University of Lund, 1976.

Braun, L. N. and Aellen, M.: Modelling discharge of glacierized basins assisted by direct measurements of glacier mass balance, IAHS Publ., 193, 99-106, 1990.
HESSD

$8,1507-1540,2011$

\section{Estimation of future glaciation and runoff in the Tanimas basin, Eastern Pamirs}

W. Hagg et al.

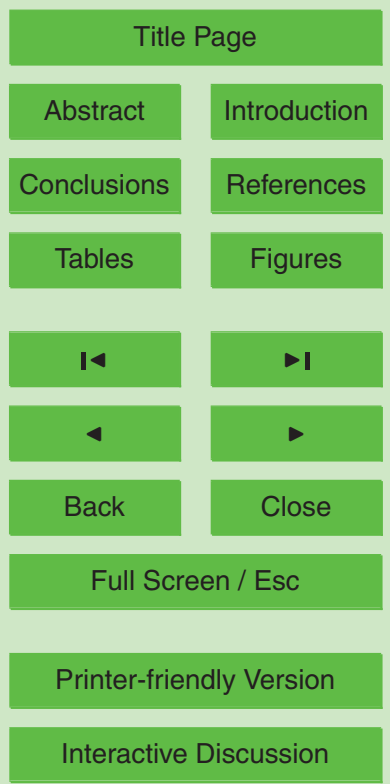


Braun, L. N. and Hagg, W.: Present and future impact of snow cover and glaciers on runoff from mountain regions - comparison between Alps and Tien Shan, in: Assessment of Snow, Glacier and Water Resources in Asia, edited by: Braun, L., Hagg, W., Severskiy, I., and Young, G., IHP/HWRP-Berichte, 8, 36-43, 2009.

5 Braun, L. N. and Renner, C. B.: Applications of a conceptual runoff model in different physiographic regions of Switzerland, Hydrolog. Sci. J., 73, 217-231, 1992.

Braun, L. N., Grabs, W., and Rana, B.: Application of a Conceptual Precipitation-Runoff Model in the Langtang-Khola Basin, Nepal Himalaya, IAHS Publ., 218, 221-237, 1993.

Braun, L. N., Weber, M., and Schulz, M.: Consequences of climate change for runoff from Alpine regions, Ann. Glaciol., 31, 19-25, 2000.

Conrad, C., Dech, S. W., Hafeez, M., Lamers, J. P. A., Martius, C., and Strunz, G.: Mapping and assessing water use in a Central Asian irrigation system by utilizing MODIS remote sensing products, Irrig. Drainage Syst., 21, 197-218, doi:10.1007/s10795-007-9029-z, 2007.

Farinotti, D., Huss, M., Bauder, A., Funk, M., and Truffer, M.; A method for estimating the ice 15 volume and ice thickness distribution of alpine glaciers, J. Glaciol., 191, 422-430, 2009.

Froebrich, J. and Kayumov, O.: Water management aspects of Amu Darya, in: Dying and Dead Seas - Climatic Versus Anthropic Causes, Kluwer Academic Publishers, Dordrecht, The Netherlands, 49-76, 2004.

Glantz, M. H.: Water, climate, and development issues in the Amu Darya Basin, Mitigation Adaptation Strategies Global Change, 10, 23-50, doi:10.1007/s11027-005-7829-8, 2005.

Haeberli, W. and Hoelzle, M.: Application of inventory data for estimating characteristics of and regional climate-change effects on mountain glaciers: a pilot study with the European Alps, Ann. Glaciol., 21, 206-212, 1995.

Hagg, W., Braun, L. N., Uvarov, V., and Makarevich, K. G.: Comparison of three methods for mass balance determination in the Tuyuksu glacier region, Tien Shan, J. Glaciol., 171, 505-510, 2004.

Hagg, W., Braun, L. N., Weber, M., and Becht, M.: Runoff modeling in glacierized Central Asian catchments for present-day and future climate, Nord. Hydrol., 37, 93-105, 2006.

Hagg, W., Braun, L. N., Kuhn, M., and Nesgaard, T. I.: Modeling of hydrological response to climate change in glacierized Central Asian catchments, J. Hydrol, 332, 40-53, 2007.

Hagg, W., Shahgedanova, M., Mayer, C., Lambrecht, A., and Popvnin, V.: A sensitivity study for water availability in the Northern Caucasus based on climate projections, Global Planet. Change, 73, 161-171, doi:10.1016/j.gloplacha.2010.05.005, 2010.
HESSD

8, 1507-1540, 2011

\section{Estimation of future glaciation and runoff in the Tanimas basin, Eastern Pamirs}

W. Hagg et al.

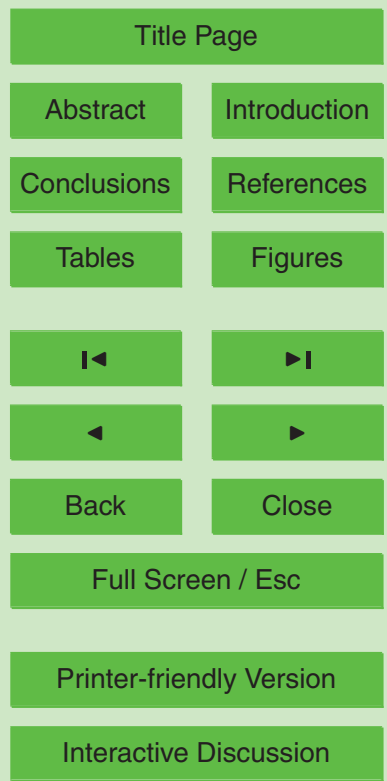


Hock, R.: Temperature index melt modelling in mountain areas, J. Hydrol., 282, 104-115, doi:10.1016/S0022-1694(03)00257-9, 2003.

Hoelzle, M. and Haeberli, W.: Simulating the effects of mean annual air temperature changes on permafrost distribution and glacier size. An example from the Upper Engadin, Swiss Alps, Ann. Glaciol., 2, 400-405, 1995.

Hoelzle, M., Haeberli, W., Dischl, M., and Peschke, W.: Secular glacier mass balances derived from cumulative glacier length changes, Global Planet. Change, 36, 295-306, 2003.

Hoelzle, M., Chinn, T. J., Stumm, D., Paul, F., Zemp, M., and Haeberli, W.: The application of inventory data for estimating characteristics of and regional past climate-change effects on mountain glaciers: a comparison between the European Alps and the New Zealand Alps, Global Planet. Change, 56, 69-82, 2007.

Hoelzle, M., Hagg, W., and Wagner, S.: Future glaciation and river flow in the Vakhsh and Panj drainage basins, Central Asia, EGU General Assembly, Vienna, Austria, 2-7 May 2010, EGU2010-6285, 2010.

15 Huss, M.: Present and future contribution of glacier storage change to runoff from macroscale drainage basins in Europe, Water Resour. Res., submitted, 2011.

Huss, M., Farinotti, D., Bauder, A., and Funk, M.: Modelling runoff from highly glacierized alpine drainage basins in a changing climate, Hydrol. Process., 22, 3888-3902, 2008.

Huss, M., Jouvet, G., Farinotti, D., and Bauder, A.: Future high-mountain hydrology: a new parameterization of glacierretreat, Hydrol. Earth Syst. Sci., 14, 815-829, doi:10.5194/hess14-815-2010, 2010.

ICWC: http://www.icwc-aral.uz/bwoamu.htm, last access: 21 November 2010.

Jansson, P., Hock, R., and Schneider, P.: The concept of glacier storage: a review, J. Hydrol., 282, 116-129, 2003.

Jòhannesson, T., Raymond, C., and Waddington, E.: Time-scale for adjustment of glaciers to changes in mass balance, J. Glaciol., 121, 355-369, 1989.

Jouvet, G., Huss, M., Blatter, H., Picasso, M., and Rappaz, J.: Numerical simulation of Rhonegletscher from 1874 to 2100, J. Comput. Phys., 228, 6426-6439, 2009.

Juen, I., Kaser, G., and Georges, C.: Modelling observed and future runoff from a glacierized tropical catchment (Cordillera Blanca, Perú), Global Planet. Change, 59, 37-48, 2007.

Kaser, G., Großhauser, M., and Marzeion, B.: Contribution potential of glaciers to water availability in different climate regimes, P. Natl. Acad. Sci. USA, 107, 20223-20227, 2010.

Koboltschnig, G. R., Schoener, W., Zappa, M., Kroisleitner, C., and Holzmann, H.: Runoff mod-

HESSD

$8,1507-1540,2011$

\section{Estimation of future glaciation and runoff in the Tanimas basin, Eastern Pamirs}

W. Hagg et al.

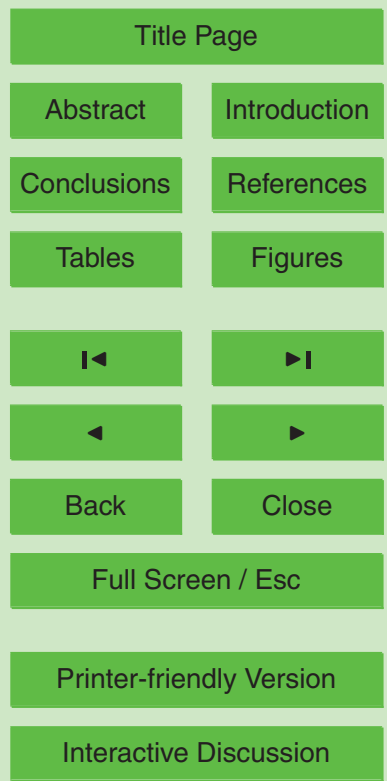


elling of the glacierized Alpine Upper Salzach basin (Austria): multi-criteria result validation, Hydrol. Process., 22, 3950-3964, doi:10.1002/hyp.7112, 2008.

Konz, M., Uhlenbrook, S., Braun, L., Shrestha, A., and Demuth, S.: Implementation of a process-based catchment model in a poorly gauged, highly glacierized Himalayan headwater, Hydrol. Earth Syst. Sci., 11, 1323-1339, doi:10.5194/hess-11-1323-2007, 2007.

Kuhn, M.: The response of the equilibrium line altitude to climatic fluctuations: Theory and observations, in: Glacier fluctuations and climatic change, edited by: Oerlemans, J., Kluwer, Dodrecht, The Netherlands, 407-417, 1989.

Kuhn, M.: Possible future contributions to sea level change from small glaciers, in: Climate and sea level change observations, projections and implications, edited by: Warrick, R. A., Barrow, E. M., and Wigley, T. M. L., Cambridge University Press, Cambridge, UK, 134-143, 1993.

Lambrecht, A. and Mayer, C.: Temporal variability of the non-steady contribution from glaciers to water discharge in western Austria, J. Hydrol., 376, 353-36, 2009.

Lambrecht, A., Mayer, C., Surazakov, A., and Aizen, V.: Changes of Fedchenko Glacier, Pamir, during the last 81 years. EGU General Assembly, Vienna, Austria, 2-7 May 2010, EGU20101522, 2010.

Le Meur, E., Gagliardini, O., Zwinger, T., and Ruokolainen, J.: Glacier flow modelling: a comparison of the Shallow Ice Approximation and the full-Stokes solution, Physique, 5, 709-722, 2004.

March, R. S.: Mass balance, meteorological, ice motion, surface altitude, runoff, and ice thickness data at Gulkana Glacier, Alaska, 1995 balance year, US Geological Survey Water Resources Investigations, 2000.

Martius, C., Froebrich, J., and Nuppenau, E.-A.: Water Resource Management for Improving Environmental Security and Rural Livelihoods in the Irrigated Amu Darya Lowlands. Hexagon Series on Human and Environmental Security and Peace, 4, 749-761, doi:10.1007/978-3540-68488-6_57, 2009.

Meehl, G. A., Stocker, T. F., Collins, W. D., Friedlingstein, P., Gaye, A. T., Gregory, J. M., Kitoh, A., Knutti, A., Murphy, J. M., Noda, A., Raper, S. C. B., Watterson, I. G., Weaver, A. J., and Zhao, Z.-C.: Global Climate Projections, in: Climate Change 2007: The Physical Science Basis. Contribution of Working Group I to the Fourth Assessment Report of the Intergovernmental Panel on Climate Change, edited by: Solomon, S., Qin, D., Manning, M., Chen, Z., Marquis, M., Averyt, K. B., Tignor, M., and Miller, H. L., Cambridge University

\section{HESSD}

8, 1507-1540, 2011

\section{Estimation of future glaciation and runoff in the Tanimas basin, Eastern Pamirs}

W. Hagg et al.

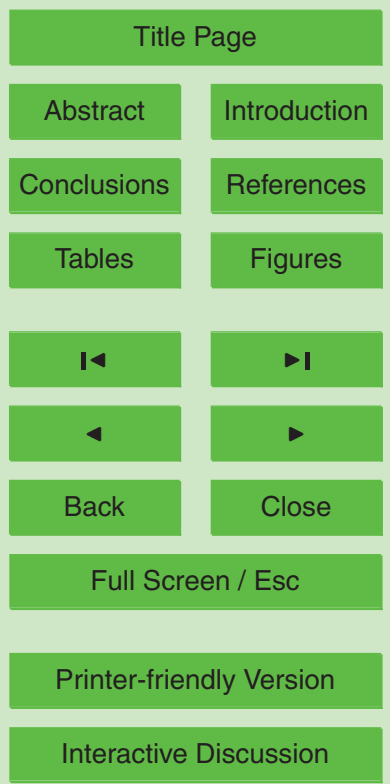


Press, Cambridge, UK and New York, USA, 747-845, 2007.

Micklin, P.: The Aral Sea Disaster, Annu. Rev. Earth Planet. Sci., 35, 47-72, 2007.

Nash, J. E. and Sutcliffe, J. V.: River flow forecasting through conceptual models. Part la discussion of principles, J. Hydrol., 10, 282-290, 1970.

5 Paterson, W. S. B.: The Physics of Glaciers, 3rd edition, Pergamon Press, Oxford, 380 pp., 1994.

Pertziger, F.: Abramov Glacier Data Reference Book: Climate, Runoff, Mass Balance, SANIIGMI, Tashkent, Uzbekistan, 279 pp., 1996.

Schaefli, B. and Huss, M.: Simulation of high mountainous discharge: how much information do we need?, Hydrol. Earth Syst. Sci. Discuss., 7, 8661-8702, doi:10.5194/hessd-7-86612010, 2010.

Schaefli, B., Hingray, B., Niggli, M., and Musy, A.: A conceptual glacio-hydrological model for high mountainous catchments, Hydrol. Earth Syst. Sci., 9, 95-109, doi:10.5194/hess-9-952005, 2005.

Schaefli, B., Hingray, B., and Musy, A.: Climate change and hydropower production in the Swiss Alps: quantification of potential impacts and related modelling uncertainties, Hydrol. Earth Syst. Sci., 11, 1191-1205, doi:10.5194/hess-11-1191-2007, 2007.

Stahl, K., Moore, R., Shea, J., Hutchinson, D., and Cannon, A.: Coupled modelling of glacier and streamflow response to future climate scenarios, Water Resour, Res., 44, W02422, doi:10.1029/2007WR005956, 2008.

UNEP: Tajikistan: State of the Environment 2005, United Nations Environment Programme, 115 pp., 2006.

UNESCO: The United Nations World Water Development Report 3: Water in a Changing World, UNESCO, Paris and Earthscan, London, 318 pp., 2009.

Verbunt, M., Gurtz, J., Jasper, K., Lang, H., Warmerdam, P., and Zappa, M.: The hydrological role of snow and glaciers in alpine river basins and their distributed modeling, J. Hydrol., 282, 36-55, 2003.

Viviroli, D. and Weingartner, R.: The hydrological significance of mountains: from regional to global scale, Hydrol. Earth Syst. Sci., 8, 1017-1030, doi:10.5194/hess-8-1017-2004, 2004.

30 Weber, M., Braun, L., Mauser, W., and Prasch, M.: The relevance of glacier melt for the upper Danube River discharge today and in the future, Mitteilungsblatt des Hydrographischen Dienstes in Österreich, Nr. 86, 1-29, 2009.
HESSD

8, 1507-1540, 2011

\section{Estimation of future glaciation and runoff in the Tanimas basin, Eastern Pamirs}

W. Hagg et al.

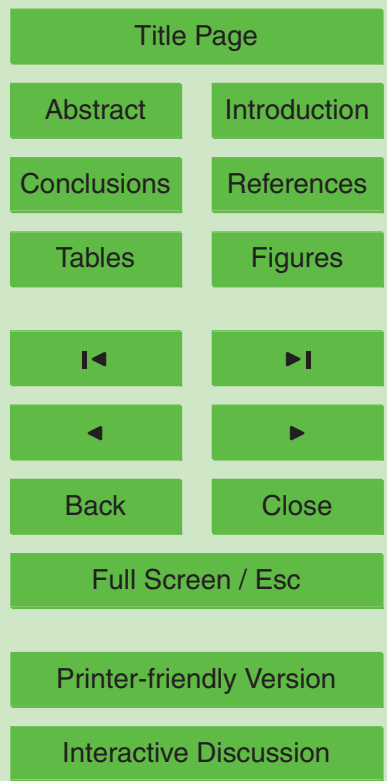


Weber, M., Braun, L., Mauser, W., and Prasch, M.: Contribution of rain, snow- and icemelt in the upper Danube discharge today and in the future, Geogr. Fis. Dinam. Quat., 33, 221-230, 2010.

WGMS: World glacier inventory - status 1989, edited by: Haeberli, W., Bösch, H., Scherler, K., 5 Østrem, G., and Wallen, C. C., IAHS/(ICSI)/UNEP/UNESCO, Nairobi, 458 pp, 1989.

\section{HESSD}

$8,1507-1540,2011$

\section{Estimation of future glaciation and runoff in the Tanimas basin, Eastern Pamirs}

W. Hagg et al.

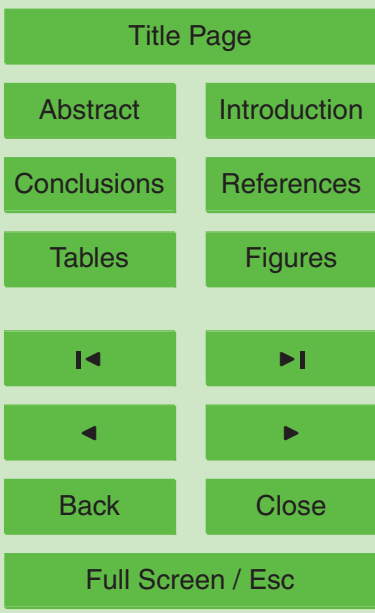

Printer-friendly Version

Interactive Discussion 


\section{HESSD}

$8,1507-1540,2011$

Table 1. Description of the free parameters in the HBV-ETH model, their units and their values found by calibration.

\begin{tabular}{llrr}
\hline Parameter & Description & Unit & Value \\
\hline RCF & rainfall correction factor & - & 1.10 \\
SCF & snowfall correction factor & - & 1.18 \\
PGRAD & precipitation gradient & $\% / 100 \mathrm{~m}$ & 5.7 \\
TGRAD & temperature gradient & ${ }^{\circ} \mathrm{C} / 100 \mathrm{~m}$ & -0.60 \\
T0 & temperature divider (also general temperature correction) & - & -0.1 \\
CMIN & minimum degree day factor on 21 December & $\mathrm{mm}^{\circ} \mathrm{C}^{-1}$ day & 2.7 \\
CMAX & maximum degree day factor on 21 June & $\mathrm{mm}^{\circ} \mathrm{C}^{-1}$ day & 3.86 \\
CWH & water holding capacity of snow & - & 0.4 \\
CRFR & coefficient of refreezing & - & 0.01 \\
ETMAX & maximum evapotranspiration on 1 August & $\mathrm{mm} \mathrm{day}^{-1}$ & 3.5 \\
LP & limit for potential evapotranspiration & $\mathrm{mm}$ & 120 \\
FC & field capacity & $\mathrm{mm}$ & 180 \\
BETA & coefficient to calculate outflow of soil moisture storage & - & 0.25 \\
LUZ & filling level of upper storage above which surface runoff occurs & - & 40 \\
CPERC & percolation from upper to lower storage & $\mathrm{mm} \mathrm{day}^{-1}$ & 0.5 \\
$k_{0}$ & storage discharge constant & - & 0.03 \\
$k_{1}$ & storage discharge constant & - & 0.016 \\
$k_{2}$ & storage discharge constant & - & 0.002 \\
\hline & & &
\end{tabular}

\section{Estimation of future glaciation and runoff in the Tanimas basin, Eastern Pamirs}

W. Hagg et al.

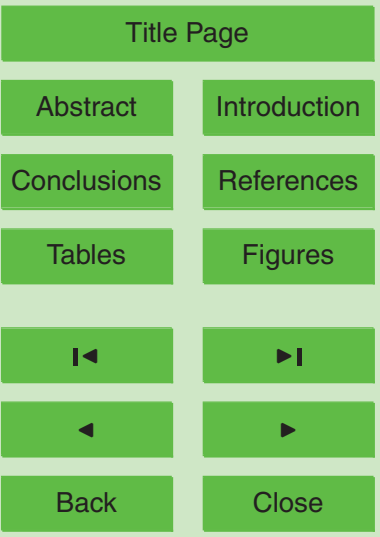

Full Screen / Esc

Printer-friendly Version

Interactive Discussion 
HESSD

$8,1507-1540,2011$

\section{Estimation of future glaciation and runoff in the Tanimas basin, Eastern Pamirs}

W. Hagg et al.

Table 2. Expected seasonal precipitation (\% rate of base norm calculated for 1961-1990) for the Fedchenko glacier station in 2050 (after Agaltseva et al., 2005).

\begin{tabular}{lccccc}
\hline Emission Scenario & Winter & Spring & Summer & Autumn & Year \\
\hline A2 & 3.0 & 0.2 & 4.7 & 7.7 & 3.1 \\
A1F1 & 8.5 & -3.7 & 6.6 & 9.2 & 3.9 \\
\hline
\end{tabular}

Title Page

Abstract

Introduction

Conclusions

References

Tables

Figures

14

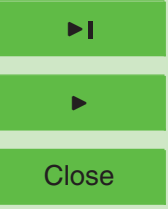

Back

Full Screen / Esc

Printer-friendly Version

Interactive Discussion 
HESSD

$8,1507-1540,2011$

\section{Estimation of future glaciation and runoff in the Tanimas basin, Eastern Pamirs}

W. Hagg et al.

Table 3. Relative monthly runoff changes by 2050 for the two climate scenarios in comparison to the calibration period (1985/1986-1989/1990).

\begin{tabular}{lccccccccccccc}
\hline & Oct & Nov & Dec & Jan & Feb & Mar & Apr & May & Jun & Jul & Aug & Sep & Year \\
\hline$+2.2^{\circ} \mathrm{C}(\mathrm{A} 2)$ & 0.97 & 1.03 & 1.02 & 1.02 & 1.02 & 1.02 & 1.11 & 1.55 & 1.28 & 0.83 & 0.74 & 0.88 & 0.97 \\
$+3.1^{\circ} \mathrm{C}(\mathrm{A} 1 \mathrm{~F} 1)$ & 1.02 & 1.08 & 1.05 & 1.05 & 1.05 & 1.05 & 1.26 & 2.09 & 1.37 & 0.75 & 0.71 & 0.91 & 1.00
\end{tabular}

Title Page

Abstract

Introduction

Conclusions

References

Tables

Figures

14

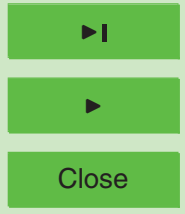

Back

Full Screen / Esc

Printer-friendly Version

Interactive Discussion 


\section{HESSD}

$8,1507-1540,2011$

\section{Estimation of future glaciation and runoff in the Tanimas basin, Eastern Pamirs}

Table 4. Mean monthly runoff derived by model runs using different approaches to implement according to the results of the parameterization scheme (Haeberli and Hoelzle, 1995), whereas "cutting lowest" excludes glacier extent in the lowest elevation classes until the anticipated total deglaciation is reached.

\begin{tabular}{llrrrr}
\hline & & Jun & Jul & Aug & Sep \\
\hline & elevation distributed $\left(\mathrm{m}^{3} \mathrm{~s}^{-1}\right)$ & 61.1 & 72.5 & 52.7 & 35.9 \\
$+2.2^{\circ} \mathrm{C}(\mathrm{A} 2)$ & cutting lowest $\left(\mathrm{m}^{3} \mathrm{~s}^{-1}\right)$ & 57.7 & 67.0 & 46.0 & 31.9 \\
& difference $(\%)$ & -5.6 & -7.5 & -12.7 & -11.3 \\
\hline & elevation distributed $\left(\mathrm{m}^{3} \mathrm{~s}^{-1}\right)$ & 65.3 & 65.6 & 50.6 & 37.1 \\
$+3.1^{\circ} \mathrm{C}(\mathrm{A} 1 \mathrm{~F} 1)$ & cutting lowest $\left(\mathrm{m}^{3} \mathrm{~s}^{-1}\right)$ & 62.9 & 61.3 & 47.4 & 34.8 \\
& difference $(\%)$ & -3.7 & -6.5 & -6.4 & -6.3 \\
\hline
\end{tabular}

W. Hagg et al.

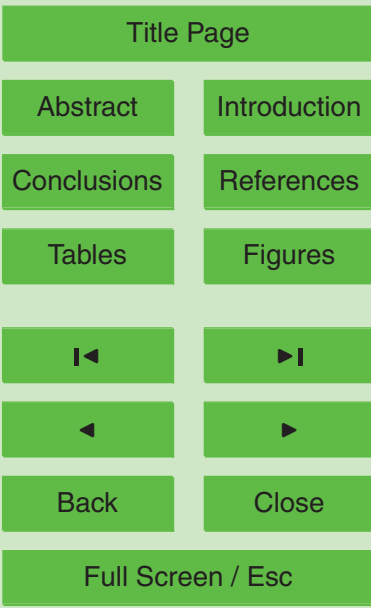

Printer-friendly Version

Interactive Discussion 
HESSD

$8,1507-1540,2011$

\section{Estimation of future glaciation and runoff in the Tanimas basin, Eastern Pamirs}

W. Hagg et al.

Table 5. Mean annual terms of the water balance as determined by the HBV-ETH-model $(Q=$ runoff, $P=$ basin precipitation, ET = basin evapotranspiration, $\Delta S_{\mathrm{g}}=$ glacier storage changes) in $\mathrm{mma}^{-1}$.

\begin{tabular}{lcccc}
\hline & $\mathrm{Q}$ & $\mathrm{P}$ & $\mathrm{ET}$ & $\Delta S_{\mathrm{g}}$ \\
\hline Calibration period & 220 & 293 & 185 & -110 \\
$+2.2^{\circ} \mathrm{C}(\mathrm{A} 2)$ & 213 & 302 & 191 & -100 \\
$+3.1^{\circ} \mathrm{C}(\mathrm{A} 1 \mathrm{~F} 1)$ & 221 & 304 & 195 & -110 \\
\hline
\end{tabular}

Title Page

Abstract Introduction

Conclusions References

Tables Figures

14

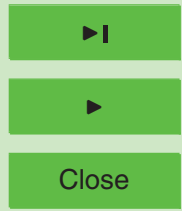

Back

Full Screen / Esc

Printer-friendly Version

Interactive Discussion 


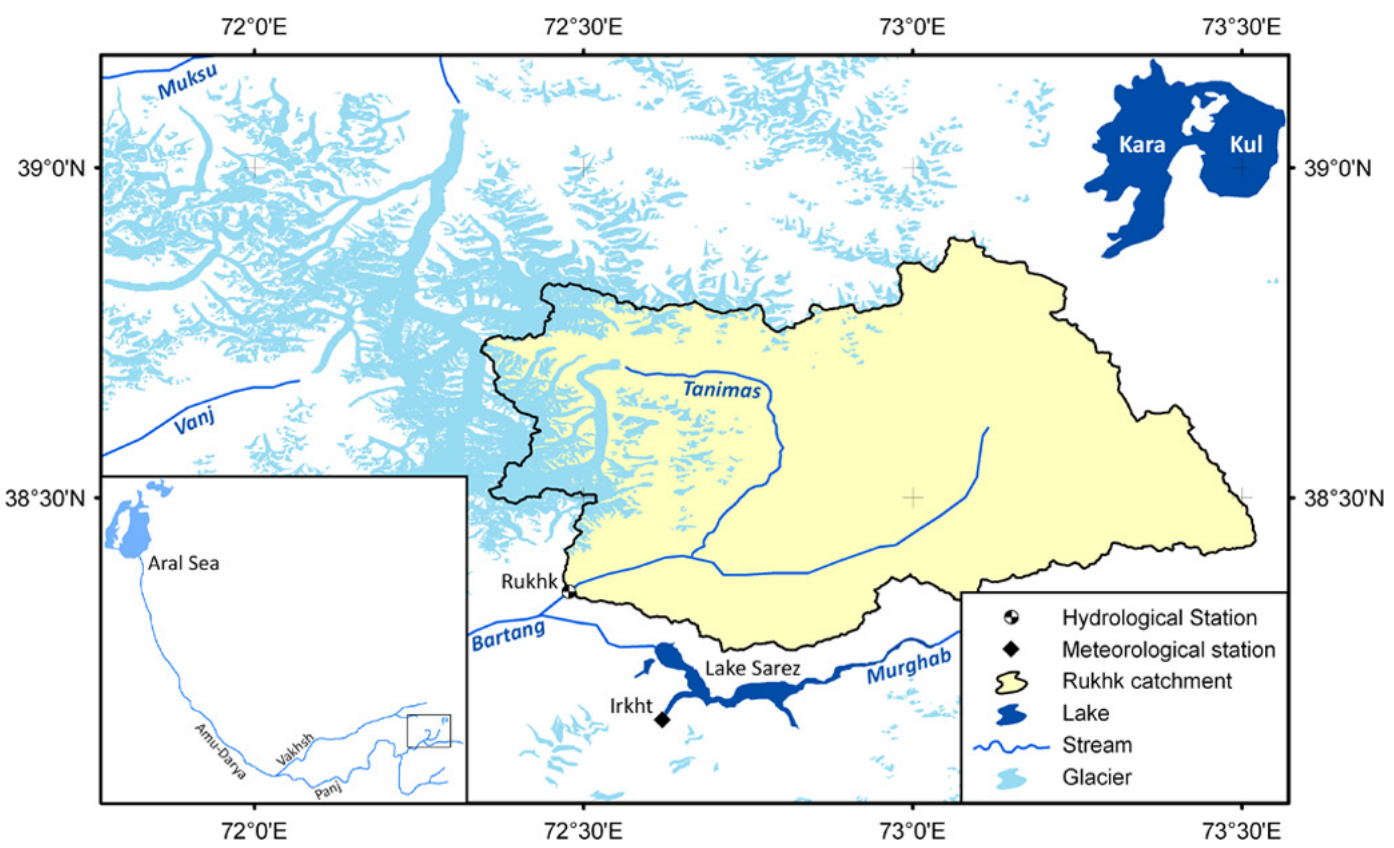

HESSD

8, 1507-1540, 2011

\section{Estimation of future glaciation and runoff in the Tanimas basin, Eastern Pamirs}

W. Hagg et al.

Title Page

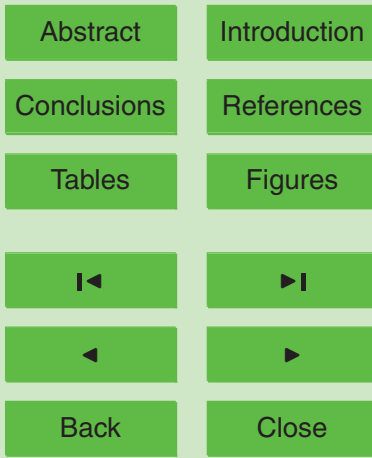

Full Screen / Esc

Printer-friendly Version

Interactive Discussion 


\section{HESSD}

$8,1507-1540,2011$

\section{Estimation of future glaciation and runoff in the Tanimas basin, Eastern Pamirs}

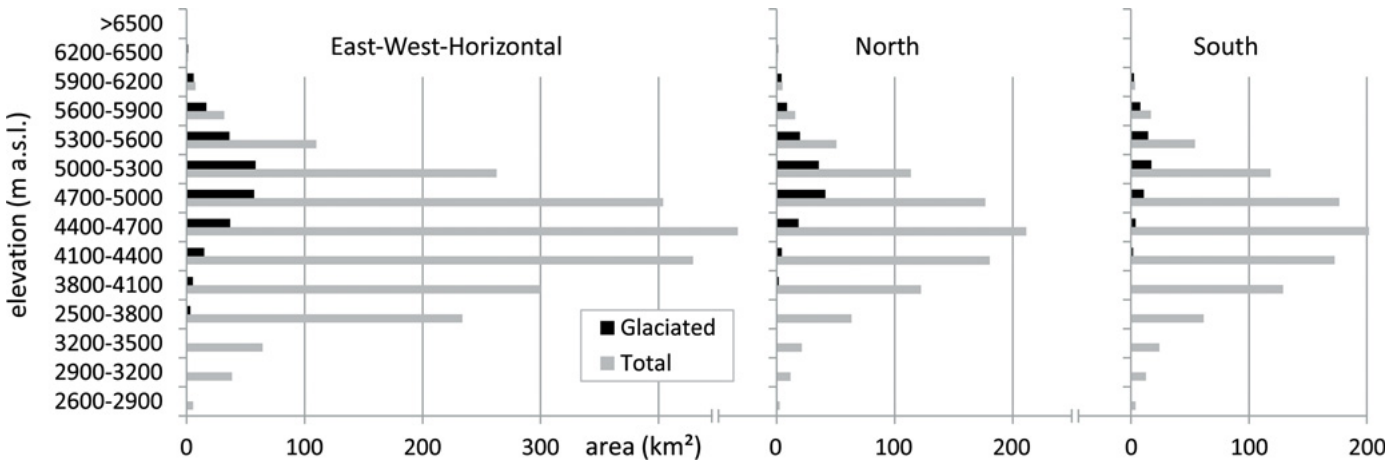

W. Hagg et al.

Fig. 2. Distribution of area by altitude and exposition classes for the total area and the glaciated part of the catchment.

Title Page

Abstract

Introduction

Conclusions

References

Tables

Figures

14

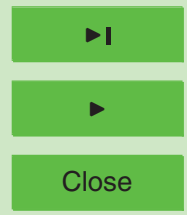

Back

Full Screen / Esc

Printer-friendly Version

Interactive Discussion 


\section{HESSD}

$8,1507-1540,2011$

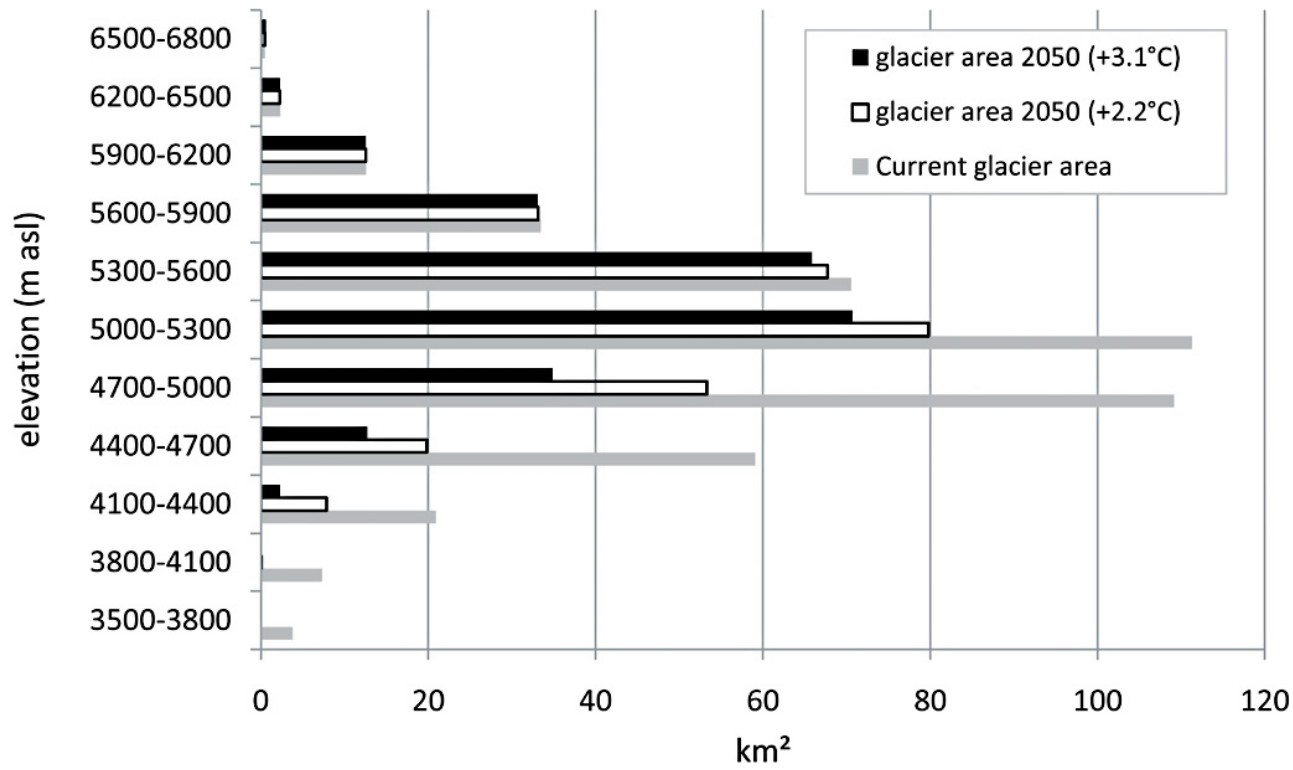

\section{Estimation of future glaciation and runoff in the Tanimas basin, Eastern Pamirs}

W. Hagg et al.

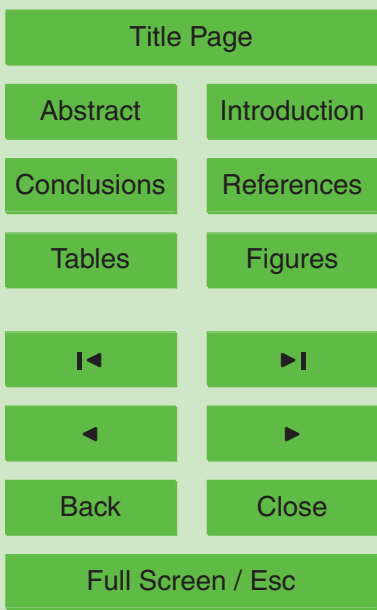

Fig. 3. Current distribution of glacier area by elevation classes and projections for the year 2050.

Full Screen / Esc

Printer-friendly Version

Interactive Discussion 


\section{HESSD}

8, 1507-1540, 2011

\section{Estimation of future glaciation and runoff in the Tanimas basin, Eastern Pamirs}

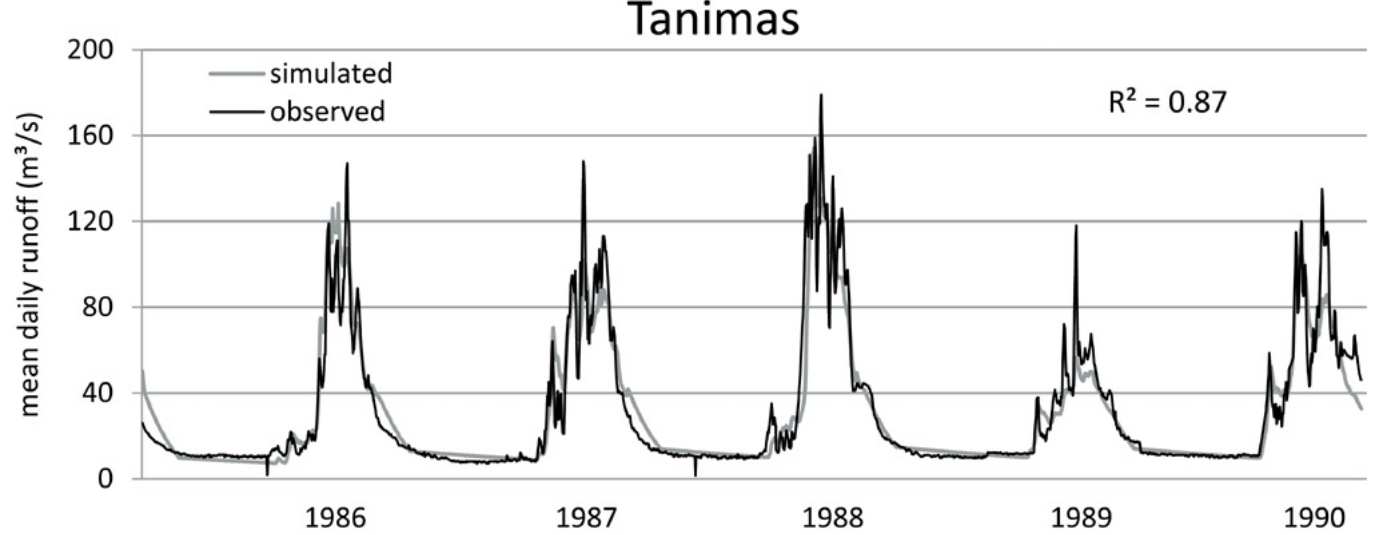

W. Hagg et al.

Fig. 4. Observed and simulated daily runoff at Rukhk $\left(R^{2}\right.$ is the model efficiency criterion after Nash and Sutcliffe, 1970).

Title Page

Abstract

Introduction

Conclusions

References

Tables

Figures

14

$\rightarrow 1$

$\triangleleft$

Back

Close

Full Screen / Esc

Printer-friendly Version

Interactive Discussion 


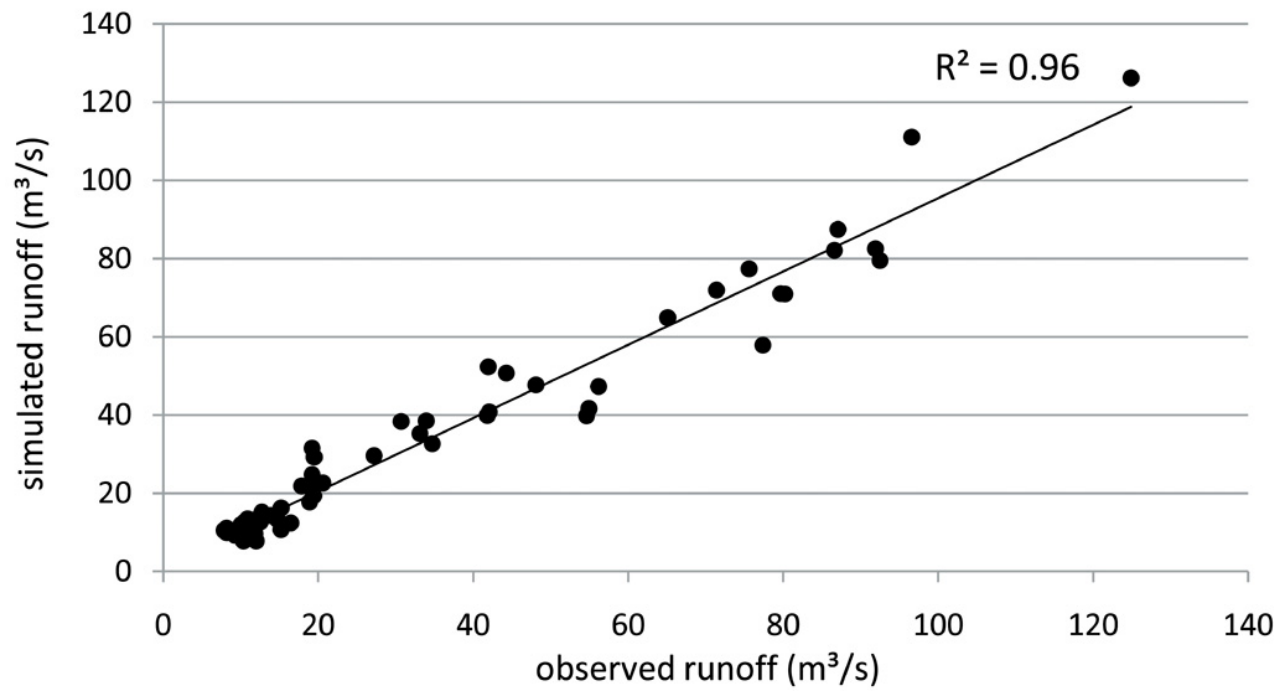

Fig. 5. Correlation between simulated and observed mean monthly runoff at Rukhk from $1986 / 1986$ to $1989 / 1990$.

\section{HESSD}

$8,1507-1540,2011$

\section{Estimation of future glaciation and runoff in the Tanimas basin, Eastern Pamirs}

W. Hagg et al.

\section{Title Page}

\section{Abstract}

Introduction

Conclusions

References

Tables

Figures

14

4

Back

Full Screen / Esc

Printer-friendly Version

Interactive Discussion 


\section{HESSD}

$8,1507-1540,2011$

Tanimas 1986/87-1989/90

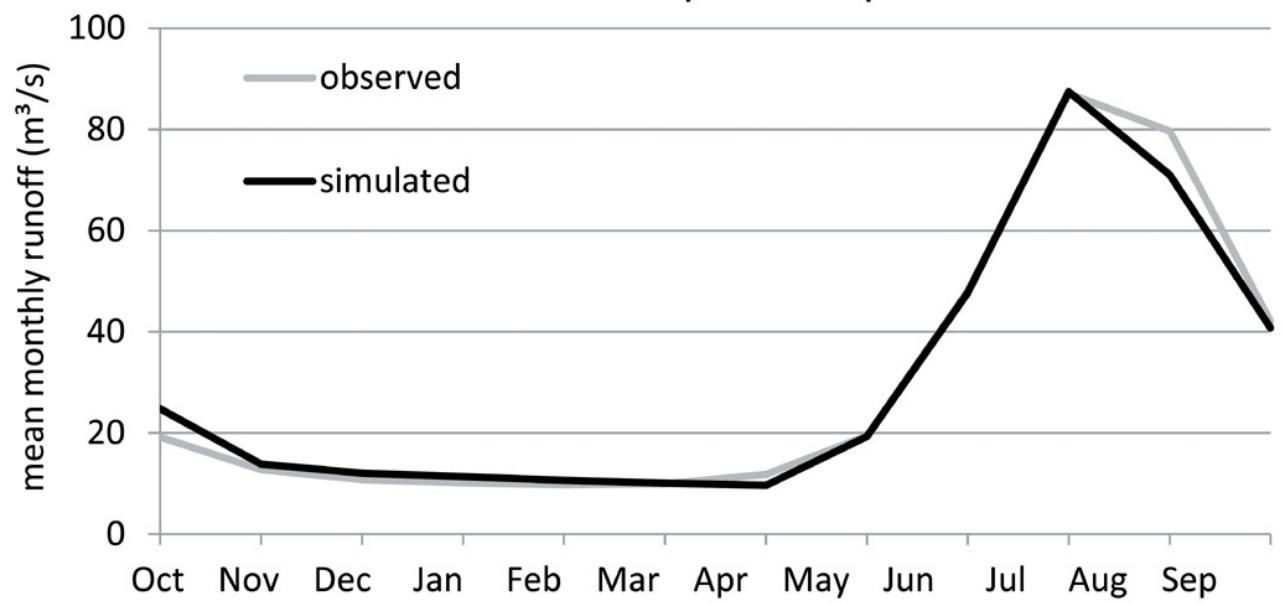

\section{Estimation of future glaciation and runoff in the Tanimas basin, Eastern Pamirs}

W. Hagg et al.

Fig. 6. Observed and simulated monthly runoff in the calibration period.

Title Page

Abstract

Introduction

Conclusions

References

Tables

Figures

14

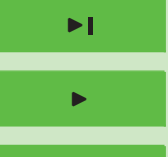

Back

Close

Full Screen / Esc

Printer-friendly Version

Interactive Discussion 


\section{HESSD}

8, 1507-1540, 2011

Runoff scenarios Tanimas 2050

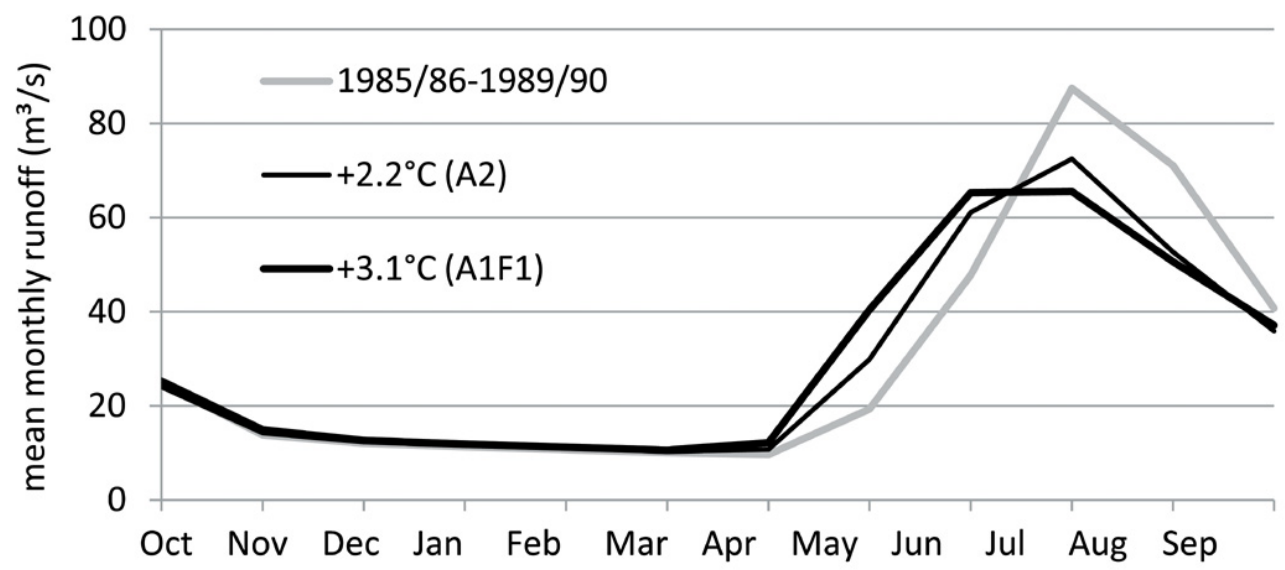

\section{Estimation of future glaciation and runoff in the Tanimas basin, Eastern Pamirs}

W. Hagg et al.

Fig. 7. Baseline and future scenarios for Tanimas river (Rukhk hydrological post).

Title Page

Abstract

Introduction

Conclusions

References

Tables

Figures

14

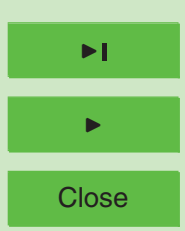

Back

Full Screen / Esc

Printer-friendly Version

Interactive Discussion 